\title{
Tariffs and the Great Depression Revisited
}

\author{
Mario J. Crucini and James A. Kahn
}

In our 1996 Journal of Monetary Economics paper, we made the following arguments:

1. Effective tariff rates during the 1930s were higher than their apparent nominal rates because of deflation.

2. Because of the importance of material inputs in traded goods, the impact of a given tariff rate could be magnified due to the impact on productive efficiency.

3. There was substantial retaliation from foreign countries in their tariff rates.

4. Consequently, even a neoclassical equilibrium model with flexible prices and no other distortions suggests that tariff increases of the order of magnitude that took place in the 1930s could have resulted in a substantial decline in output.

5. Though large enough to look like a modest recession, these model-calibrated output declines are only on the order of one-tenth the magnitude of the actual declines that occurred during the Great Depression.

Since this 1996 paper appeared in print, some new tools for business cycle analysis have emerged. In a series of papers (Hall 1997; Mulligan 2002a, 2002b; Chari, Kehoe, and McGrattan 2002; and Galí, Gertler, and López-Salido 2001), movements in output and employment have been decomposed into three sources, which amount to deviations from equilibrium conditions in the one-sector neoclassical growth model. The three conditions are an aggregate resource constraint, a static optimality condition relating consumption and leisure, and an intertemporal condition relating capital accumulation and expected consumption growth. It should be emphasized that 
this decomposition is really just an accounting framework. It does not offer a deeper explanation of the fundamental causes of fluctuations, but the results of the accounting exercise may shed some light on what the causes could and could not be, and provide a set of stylized facts with which theories must be consistent. Thus, for example, Hall (1997) finds that most employment fluctuations in postwar U.S. data appear to be accounted for by deviations in the static optimality condition relating the marginal product of labor (MPL) with the marginal rate of substitution (MRS) between consumption and leisure. This fact is consistent with any number of theories, and proposed candidates include preference shocks, distortions in labor markets resulting from taxes, unionization, and rigid prices and wages, among others. It is not consistent with theories of employment fluctuations that result in no change in the "wedge" between the MRS and MPL. On the other hand, both Hall (1997) and Chari, Kehoe, and McGrattan (2002) find that output fluctuations are composed of a mix of movements in both the MRS-MPL (or "labor") and efficiency wedges.

Similar analysis applied to the interwar period has generated more debate concerning the relative importance of the labor and efficiency wedges. Mulligan (2002a, 2002b) argues that the employment declines during this period were almost entirely attributable to an increase in the labor wedge, whereas Chari, Kehoe, and McGrattan (2002) show total factor productivity in substantial decline - at least from 1929 to 1933. Mulligan asserts that tariffs in the sort of model we proposed would result primarily in reductions in labor productivity, which in the accounting framework described earlier amounts to a distortion in the resource constraint, or an efficiency wedge. The claim is that the production inefficiency that results from the tariffs would show up as a decline in total factor productivity (TFP), and in the context of standard modeling assumptions would lead to very little change in aggregate employment.

In light of these more recent developments, we return here to the argument in our 1996 paper. We will show, first, that tariff increases in our model do indeed correspond to an increased efficiency wedge in a prototype one-sector model. This would seem to support Mulligan's view that tariffs were not an important factor in the Great Depression. His argument is problematic for two reasons, however. First, the source of the wedge in the trade model is due to the production inefficiencies that arise when the domestic (and foreign) country imposes a tariff on imported intermediate goods. Since the production possibilities of each final goods sector are not altered by the imposition of the tariffs, a standard Solow accounting exercise should not generate measurable fluctuations in total factor productivity as measured by Chari, Kehoe, and McGrattan. Thus, the magnitude of measured TFP move- 
ments has little bearing on the validity of our estimates of the contribution of tariffs to the Great Depression.

Mulligan's (2002a, 2002b) second argument - that productivity did not decline in the 1930s - is debatable. Mulligan makes his argument on the basis of wage data. This is a reasonable thing to do under the null hypothesis of a flexible price equilibrium. If the production technology is Cobb-Douglas with constant share parameters, then the wage, which must equal the marginal product of labor in equilibrium, is also proportional to the average product of labor. Since real wages did not show any decline in the 1930s, it follows that the average product of labor did not decline either. The more relevant measure of productivity in discussing the efficiency wedge is total factor productivity. Total factor productivity actually shows substantial declines - at least from 1929 to 1933 - according to Chari, Kehoe, and McGrattan (2002). Using aggregate wage data to infer total factor productivity is problematic on two counts. First, there are distribution effects - to the extent that lower wage workers are disproportionately affected by unemployment, the average wage may not be affected. Of course, this problem presumably affects measured labor productivity as well. The second problem is that for whatever reason (sticky wages, labor hoarding), labor's share of income is typically countercyclical, and indeed rose substantially during the 1929-33 period. According to Mulligan's calculations, for example, labor's share of national income (excluding proprietors' income) rose from 0.71 in 1929 to 0.83 in 1933.

We conclude from our reading of the interwar productivity literature that a decline in TFP follows the peak-to-trough movements in output fairly well, with the quantitative magnitude of the swing and underlying economic reasons for the movement remaining the subject of ongoing debate. The Chari, Kehoe, and McGrattan (2002) business cycle accounting approach for measuring wedges appears to be ill-suited for characterizing the inefficiencies generated by our tariff model. More generally, the quantitative contribution of various shocks and their propagation mechanisms remain the subject of active business cycle research.

The plan of this paper is as follows. In the next section we will review the historical evidence. Then we will present the model of tariffs and economic activity from our 1996 paper, examining both the steady-state implications of permanent tariff increases and business cycle implications for cyclical variation in tariffs. Next we will use the one-sector stochastic growth model as a prototype (as suggested in Chari, Kehoe, and McGrattan 2002) to show how tariffs in our three-sector two-country model translate into wedges in the prototype model. We will then compare the implied wedges with the historical ones, and discuss the implications of our results for future research. 


\section{The Historical Context}

Our 1996 paper identified three historical facts that are essential to understanding why the macroeconomic effects of tariffs in the Great Depression were potentially much larger than had previously been thought. First, tariff levels increased both at home and abroad by a factor of at least three from 1928 to 1933 , not just from statutory changes but also from the interaction of deflation and specific (as opposed to ad valorem) tariffs. The magnitude of the tariff increases was such that they were too large to be "optimal tariffs," even for a large economy such as the United States. Further, foreign retaliation tends to wipe out such gains, leaving the United States and its major trading partners worse off. Second, the majority of imports into the United States were material inputs; as a result, tariffs introduced production distortions. Third, the tariff changes were persistent so their effects were propagated through changes in the stock of capital.

\section{Interwar Trading Patterns}

In this section we review U.S. trading patterns and present a brief tariff history. We begin with an examination of the volume and composition of trade between the United States and some of its major trading partners: Canada and Europe (consisting of France, Germany, Italy, and the United Kingdom).

The pattern of U.S. trade was quite different during the interwar period than observed today. As Table 1 indicates, U.S. trade was heavily skewed toward nonmanufactured goods. For every dollar of nonmanufactures exported, the United States exported less than fifty cents of manufactures (imports were even more skewed). Thus, the U.S. trade balance shows no obvious pattern of specialization across manufactured versus nonmanufactured goods. In contrast, France and Germany exported more than two dollars of manufactures for every dollar of nonmanufactures exported. Imports are even more skewed in

Table 1. Trade composition and U.S. trading patterns in 1925

\begin{tabular}{lcccc}
\hline & \multicolumn{2}{c}{$\begin{array}{c}\text { Trade ratio: Manufactures } \\
\text { to nonmanufactures }\end{array}$} & \multicolumn{2}{c}{ Fraction of U.S. } \\
\hline & Exports & Imports & Exports & Imports \\
\hline United States & 0.48 & 0.29 & - & - \\
Canada & 0.78 & 1.31 & 15.6 & 11.0 \\
France & 2.30 & 0.27 & 5.7 & 4.1 \\
Germany & 2.54 & 0.18 & 9.6 & 3.9 \\
Italy & NA & NA & 4.2 & 2.4 \\
United Kingdom & NA & NA & 21.0 & 9.7 \\
\hline
\end{tabular}


the opposite direction, favoring raw materials. Thus, the industrialized countries of Europe had a distinctive pattern of specialization that favored manufactured goods. Canada's exports were reasonably balanced across categories, but imports favored manufactures very strongly. In terms of trading partners, Canada and the United Kingdom were the two most important sources and destinations for U.S. products. Canada's geographic proximity was probably important, as was the United Kingdom's dominant position in world trade.

\section{A Brief Tariff History}

Much of the historical tariff literature has focused on questions of political economy, most prominently in the U.S. case, by Frank Taussig (1931) and more recently in studies that focus on the Hawley-Smoot tariffs by Eichengreen (1989) and Irwin and Kroszner (1996): Why was such a bill passed at such a crucial time? Who benefited (ex ante) and who lost? While the political origins of interwar tariffs are by now fairly well understood (as classic examples of political log-rolling), their macroeconomic impact is not, and this is the question on which we focus.

Many countries passed legislative increases just after World War I and again during the period from 1927 to 1932 . Historians emphasize internal reasons for the escalation of tariff levels following the war and emphasize international retaliation in the wake of the infamous Hawley-Smoot Tariff Act during the 1930 s. ${ }^{1}$

Table 2 reports summary statistics for international tariff indexes computed as the ratio of customs duties to total imports (except for the United States, where the ratio of customs duties to dutiable imports is also presented). Using total imports (to be consistent with data available from other countries), tariffs in the United States rose from the level of 13 percent during the 1920s to 16.6 percent during the $1930 \mathrm{~s}$, while those in most European countries more than tripled. Comparing these numbers gives the impression that the United States bore the brunt of the tariff escalation. On a U.S. trade-weighted basis, however, things look more symmetric with foreign tariffs rates rising from 9.9 percent to 19.9. These numbers reflect the more modest increases in tariffs imposed by Canada and the United Kingdom (from all sources) and the fact that these two countries account for a considerable fraction of U.S. exports. Although these estimates provide a useful starting point, there are reasons to interpret them with caution.

First, as is well-known, revenue-based tax measures tend to be downward biased as individuals substitute from high-tax goods to low-tax goods. At the extreme, prohibitive tariffs receive no weight at all. Using a constant import share-weighted tariff index for thirty-two major U.S. imports, Crucini (1994) estimates that the average tariff level increases from 15 percent in 1920 to 120 


\section{Table 2. International tariff levels}

\begin{tabular}{lcc}
\hline & \multicolumn{2}{c}{$\begin{array}{c}\text { Average ad valorem } \\
\text { equivalent tariffs }\end{array}$} \\
\cline { 2 - 3 } United States & $1920-29$ & $1930-40$ \\
\hline Total imports & 13.0 & 16.6 \\
Dutiable imports & 35.1 & 44.5 \\
Other countries & & \\
\hline Trade-weighted average & 9.9 & 19.9 \\
Canada & 13.4 & 15.2 \\
France & 7.1 & 21.0 \\
Germany & 7.2 & 26.1 \\
Italy & 4.5 & 16.8 \\
United Kingdom & 9.8 & 23.2 \\
\hline
\end{tabular}

percent in 1932, compared to an increase from 11 percent to a tariff level of 98 percent for the variable import share index. By this metric, the variable import share index understates the level of tariffs by about 20 percent in 1932.

Second, the tariffs are computed using imports from all locations, yet countries tend to levy country-specific rates, which is particularly relevant before the General Agreement on Tariffs and Trade (GATT). We know that one reaction to Hawley-Smoot during the early 1930s was for Canada and the United Kingdom to increase duties on goods imported from the United States while maintaining Commonwealth preference. Aggregative bilateral tariff indexes are available for Canada and show exactly this type of pattern. The average duty on Canadian imports from the United States rose by 27 percent from 14.1 in 1929 to 17.9 percent in 1932, while the average duty on Canadian imports from the United Kingdom rose by only 6 percent from 20.6 to 21.9 during the same period. ${ }^{2}$ As a result, the increase in the Canadian tariff index reported in Table 2 understates the tariff increases on U.S. exports to Canada. Given the large increases in tariff rates by France, Germany, and the United Kingdom, it would be interesting to investigate if the increases were even greater for imports from the United States.

Finally, the tariff levels are often quite heterogeneous across goods, which may make the averages of dubious value in assessing commercial policy. The heterogeneity in tariff levels is evident in comparing the implied ad valorem rate on total imports and dutiable imports. We see that for the United States, items subject to duty were taxed at rates closer to 35 to 45 percent, not the 15 percent suggested by the rates computed using total imports. 


\section{The Model}

With the preceding historical analysis as background, we would argue that an empirically plausible model must (a) incorporate the fact that tariff changes were persistent and volatile, (b) include an important role for trade in intermediate inputs, and (c) incorporate the fact that the countries involved in the trade war were large enough to affect world prices. We incorporate each of these features into a tractable aggregative model, drawing from two strands of quantitative equilibrium theory.

The first strand of the literature is real business cycle research, which has focused on economic fluctuations over time with particular attention given to the process of intertemporal choice under rational expectations. The dynamic features of real business cycle (RBC) models allow us to capture the effects of both temporary and permanent tariff changes on investment and labor supply decisions. As we shall see, endogenous capital and labor supply decisions are essential in generating plausible aggregative effects of tariffs. Our modeling approach has also been heavily influenced by the computable general equilibrium (CGE) literature, which has long emphasized the economic significance of the large volume of trade in intermediate goods and the production inefficiencies that arise when these trade flows are taxed. At the macroeconomic level, we will additionally want to incorporate the fact that the nontraded consumption goods sector is large relative to the traded goods sector.

To match these observations and modeling considerations, each country must produce three goods: (a) a nontraded consumption-investment good, (b) a traded consumption good, and (c) materials. We adopt the Armington (1969) assumption common in the trade literature, treating the traded final goods as imperfect substitutes in consumption and the traded material inputs as imperfect substitutes in production.

Consumers in each country choose consumption of the home nontradable $C_{1 t}$, consumption of the home export $C_{2 t}$, consumption of the foreign export $C_{3 t}$, and leisure $L_{t}$ to maximize

$$
E(U)=E_{0} \sum_{t=0}^{\infty} \beta^{t} U\left(C_{1 t}, C_{2 t}, C_{3 t}, L_{t}\right)=E_{0} \sum_{t=0}^{\infty} \beta^{t} \log C_{t}+\kappa L_{t}
$$

in the case of the home country and

$$
E(U)=E_{0} \sum_{t=0}^{\infty} \beta^{t} U\left(C_{1 t}^{*}, C_{2 t}^{*}, C_{3 t}^{*}, L_{t}^{*}\right)=E_{0} \sum_{t=0}^{\infty} \beta^{t} \log C_{t}^{*}+\kappa L_{t}^{*}
$$


in the case of the foreign country. The relationship between aggregate consumption and leisure follows Rogerson (1988), who considers environments in which nonconvexities in the labor-leisure choice at the individual level result in "representative agent" preferences that are linear in leisure. The variable $C$ is a composite variable representing constant elasticity of substitution (CES) aggregation of individual consumption components:

$$
C \equiv\left[b_{1} C_{1}^{-\gamma}+b_{2} C_{2}^{-\gamma}+b_{3} C_{3}^{-\gamma}\right]^{-\frac{1}{\gamma}}
$$

The CES function for consumption goods captures the idea that domestic and foreign goods are imperfect substitutes. The weights $b_{1}, b_{2}$, and $b_{3}$ influence how consumption expenditure is allocated across goods.

A single representative agent (in each country) allocates market time across the three sectors of the domestic economy and leisure subject to the constraint that these activities exhaust total hours available (which we normalize to unity).

$$
1-L_{t}-N_{1 t}-N_{2 t}-N_{4 t} \geq 0
$$

The foreign country faces an analogous constraint:

$$
1-L_{t}^{*}-N_{1 t}^{*}-N_{3 t}^{*}-N_{4 t}^{*} \geq 0
$$

Implicit in these constraints is the fact that labor is completely mobile across sectors within the period, yet immobile across countries.

The functional forms that describe our production sectors are given by equations (6) and (7). Domestic output in each sector is produced with capital, labor, and a fixed proportion of intermediate inputs. Letting $Y_{i t}$ denote gross output in sector $i$, and for the moment ignoring the intermediate input requirement, we have

$$
Y_{i t}=F\left(K_{i t}, N_{i t}\right)=K_{i t}^{\alpha_{i}} N_{i t}^{1-\alpha_{i}}, \quad i=1,2,4
$$

for the home country, while the foreign country produces the goods according to

$$
Y_{i t}^{*}=F\left(K_{i t}^{*}, N_{i t}^{*}\right)=K_{i t}^{* \alpha_{i}} N_{i t}^{* 1-\alpha_{i}}, \quad i=1,3,4 .
$$

Note that production occurs in sectors 1, 2, and 4 in the home country, and in sectors 1,3 , and 4 of the foreign country. 
Each sector of the economy requires intermediate goods as a Leontief input into production (Leontief 1941). The fixed intermediate input requirement for the production of good $i$ is $\theta_{i} Y_{i t}$. The input requirements are themselves combinations of domestic and foreign raw materials, denoted $m_{h h t}$ and $m_{f h t}$, where the first subscript indicates the location of production of the raw material and the second indicates where that material is being combined for use in final production. The home composite intermediate good is given by

$$
\begin{aligned}
M_{t} & =G\left(m_{h h t}, m_{f h t}\right)=\left[\psi m_{h h t}^{-\sigma}+(1-\psi) m_{f h t}^{-\sigma}\right]^{-1 / \sigma} \\
& =\theta_{1} Y_{1 t}+\theta_{2} Y_{2 t}+\theta_{4} Y_{4 t},
\end{aligned}
$$

while the foreign composite is

$$
\begin{aligned}
M_{t}^{*} & =G\left(m_{f f t}, m_{h f t}\right)=\left[\psi m_{f f t}^{-\sigma}+(1-\psi) m_{h f t}^{-\sigma}\right]^{-1 / \sigma} \\
& =\theta_{1} Y_{1 t}^{*}+\theta_{3} Y_{3 t}^{*}+\theta_{4} Y_{4 t}^{*} .
\end{aligned}
$$

The parameters $\psi$ and $1-\psi$ influence the fraction of domestic materials that are used in production of domestic intermediate inputs. The second line in equations (8) and (9) indicates that composite materials produced in the current period, by a particular country, are completely exhausted by their uses across the three sectors operating within the economy.

Capital is a nontraded good and hence is produced in sector 1 of each country. Despite being immobile across countries, it is assumed to be perfectly mobile across sectors within a country. For the home country, capital obeys the standard accumulation equation

$$
K_{t+1}=(1-\delta) K_{t}+I_{t}=K_{1 t+1}+K_{2 t+1}+K_{4 t+1}
$$

and

$$
K_{t+1}^{*}=(1-\delta) K_{t}^{*}+I_{t}^{*}=K_{1 t+1}^{*}+K_{3 t+1}^{*}+K_{4 t+1}^{*}
$$

for the foreign country.

We assume that markets are complete, to simplify the solution to this model. As a result, market-clearing conditions are imposed by individual sector rather than by individual budget constraint. The resource constraints are 
(12)

$$
\begin{array}{ll}
Y_{1 t}=C_{1 t}+I_{t} & Y_{1 t}^{*}=C_{1 t}^{*}+I_{t}^{*} \\
Y_{2 t}=C_{2 t}+C_{2 t}^{*} & Y_{3 t}^{*}=C_{3 t}+C_{3 t}^{*} \\
Y_{4 t}=m_{h h t}+m_{h f t} & Y_{4 t}^{*}=m_{f f t}+m_{f h t}
\end{array}
$$

Tariff revenue equals transfers back to individuals, when combined with complete markets means the production possibilities of the distorted world economy are the same as in the undistorted economy. However, the tariffs are distortionary (i.e., they will affect consumption and production decisions) as individuals equate marginal rates of substitution and transformation to distorted equilibrium prices, and this is how allocations are affected by the presence of tariffs.

\section{Calibration}

Providing a quantitative estimate of the impact of the tariff war requires that we calibrate the twenty-eight parameters that describe preferences and technology in our model of the world economy. Fortunately, our macroeconomic focus rationalizes two convenient symmetry restrictions that together reduce the number of parameters to just ten.

Our first symmetry assumption is that the two regions, which we treat as the United States and an aggregate of its major trading partners, are completely symmetric in terms of the parameters of taste and technology. These crosscountry restrictions create a natural, and easily understandable, benchmark model in which symmetric retaliation leads to the same quantitative changes in economic variables in both countries. The number of parameters is reduced from twenty-eight to fourteen with these restrictions imposed.

The second set of symmetry assumptions is made at the sector level. We assume that the factor and material intensities are equal across sectors. In terms of the notation of our model, this requires that $\alpha_{i}=\alpha$ and $\theta_{i}=\theta$. These two assumptions have the implication that the equilibrium response to an increase in the tariff on intermediate inputs is an inward shift in the aggregate production function at unchanged marginal rates of transformation across goods within each country.

The ten parameters that remain are reported in Table 3. The first four parameters listed are often found in real business cycle models of closed economies: the discount factor, $\beta$, determines the steady-state real interest rate, $r$, which is set to 5 percent; the parameter $\kappa$ is determined such that the fraction of hours spent in the workplace, $\bar{N}$, matches the value of 0.27 , approximately a 6.5 hour workday; the historical average share of value added accounted for by rental payments to physical capital 0.30 determines $\alpha$; and 
Table 3. Model calibration

\begin{tabular}{ll}
\hline Panel A: Aggregate parameters \\
$r=\beta^{-1}-1$ & 0.05 \\
$\bar{N}$ & 0.27 \\
$\alpha$ & 0.3 \\
$\delta$ & 0.10
\end{tabular}

\begin{tabular}{lc}
\hline Panel B: Sectoral parameters \\
$\theta$ & 0.2 \\
$\psi$ & 0.8 \\
$b_{1}$ & 0.98 \\
$b_{2}, b_{3}$ & 0.01 \\
\hline \multicolumn{2}{l}{ Panel C: Elasticity parameters } \\
$\gamma$ & 0 \\
$\sigma$ & 0.6 \\
\hline Panel D: Great ratios & \\
Consumption & 0.80 \\
Investment & 0.20 \\
Exports & 0.07 \\
Imports & 0.07 \\
Tariff revenue & 0.007 \\
\hline
\end{tabular}

the depreciation rate of capital, $\delta$, is set at 10 percent per annum.

Parameters introduced by our multisector analysis are of two basic types. First we have parameters that determine additional "shares": (a) the cost share of intermediate inputs relative to value added, $\theta$; (b) the share of domestic raw materials that are combined with foreign raw materials to produce the domestic intermediate good, $\psi$; and (c) the share of nontraded goods in aggregate consumption, $b_{1}$. Second we have the elasticities of substitution: (a) across domestic and foreign consumption goods, $\gamma$; and (b) across domestic and foreign materials in the production of intermediate inputs used in domestic production, $\sigma$.

We set the cost share for intermediate inputs at 0.20 , which is in the lower range of values reported in Leontief's (1941) classic input-output study of the interwar U.S. economy. Later we will consider the importance of tariffs on materials by setting $\theta=0$ so that the sensitivity of the model's predictions to the existence of materials will be transparent. 
Leontief's study also indicates that about 80 percent of U.S. imports during the interwar period were intermediate factors of production. ${ }^{3} \mathrm{We}$ capture the importance of imported materials while minding the constraint on the total import share, setting $1-\psi$ equal to 0.20 . When the tariff levels are 10 percent, as in our initial steady state, the ratio of domestic to foreign materials is 2.5 to 1 .

The weight on imported goods in the utility function, $b_{3}$, makes up the remainder of domestic imports, such that we match the historical average of the trade shares for the United States of about 7 percent. As Table 3 indicates, this requires a weight of 0.98 on nontraded goods in the CES function for aggregate consumption services. Our symmetry assumptions require that the remainder of consumption be equally divided between imports and consumption of the domestic export. This means that the weights on the remaining consumption goods, $b_{2}$ and $b_{3}$, each equal 0.01 .

Our baseline parameterization of preferences across consumption goods is Cobb-Douglas, in which case the parameter setting $b_{1}=0.98$ means that 98 percent of aggregate consumption is accounted for by nontraded goods. When we consider the model without intermediate goods, nontraded consumption drops to 82 percent of total consumption. Thus, we will also have results that indicate the consequences of changing the quantity of consumption imports.

Finally, we must determine the values of the elasticities of substitution across domestic and foreign goods. Our baseline choice of the parameter $\gamma=0$ is consistent with a large number of empirical studies that report elasticities of substitution between domestic and foreign goods of about unity (note that the elasticity of substitution is $1 /(1+\gamma)$ ). However, we consider as wide a range of estimates of this parameter, as reported in Whalley (1985). We look at less substitution, setting $\gamma$ equal to unity, then at more substitution by setting $\gamma$ equal to $-1 / 3$. We employ a similar range of estimates for the substitutability of domestic and foreign materials but keep the baseline elasticity of substitution somewhat lower, setting $\sigma$ at 0.6 .

The investment-to-output ratio is 20 percent, having been determined by parameters that have already been set. The consumption-to-output ratio is 80 percent, given our decision to constrain the trade balance to be zero in the initial steady state. As mentioned earlier, the export share is set at 7 percent, approximately the U.S. average over this period of time. Tariff revenue as a fraction of output is 0.7 percent, which is simply the import share of 7 percent times the baseline tariff rate, which we set at 10 percent (the trade-weighted average of foreign tariff levels reported in Table 2 for the period 1920-29). 


\section{The Results}

Economists are confronted with two important and difficult tasks in any attempt to estimate the contribution of the collapse of world trade to the Depression in the United States. The first is identification: What fraction of the decline in exports should be attributed to the tariff war versus other domestic or international disturbances? The second issue is: How do we translate the change in exports into a change in aggregate activity? What is the "export multiplier"?

That the answers to these questions are important in the context of the Great Depression should be obvious. Real exports declined by almost 50 percent between 1929 and 1933, while real GNP declined by about 30 percent over the same period. Attributing the entire decline in exports to the tariff, we would explain about 10 percent of the peak-to-trough decline in GNP if the export multiplier was equal to one, and one-third of the swing if the multiplier equaled three.

Our approach is to let the calibrated model and estimates of tariff levels determine both the value of export multipliers and the quantitative decline in exports. Discussion can then be focused on the plausibility of the economic mechanisms that give rise to multipliers of different size rather than debate over ad hoc specifications of the multipliers. We also avoid the temptation to parameterize the model in such a way that it matches the quantitative decline in exports that is observed during the Depression years, since to do so would rule out any possibility of declines in international trade originating from disturbances other than the tariff war.

\section{Steady-State Implications}

We begin our quantitative analysis with the steady-state implications of a symmetric tariff war that involves permanent tariff increases. While somewhat counterfactual in the sense that the tariff increases were persistent, not literally permanent, the steady-state analysis helps us understand the key structural issues that translate tariff changes into significant macroeconomic effects even when the trade share is small.

We examine tariff wars with tariff levels rising from 10 percent to either 30 percent or 60 percent. Recall that most tariff indexes using the ratio of customs revenue to total imports moved from a low of about 10 percent in the early 1920s to highs approaching 30 percent in the 1930s. The first case is intended to match these observations. The second case deals with the problem that tariff indexes are increasingly downwardly biased as customs duties escalate toward prohibitive levels. For example, we saw that the U.S. tariff index that used only dutiable imports rose from about 15 percent in 
1920 to a high of about 60 percent in 1932.

We will begin summarizing the quantitative findings and then provide the economic intuition for the results. It will be useful to define some terminology at the outset. Let us define an "export multiplier" as the ratio of the change in output to the change in exports times the export share. For example, if after an escalation of tariff levels, exports fall by 10 percent and the export share is 7 percent, an export multiplier of 1 would mean output is predicted to fall by 0.7 percent.

Table 4 presents the main results of our steady-state analysis. We consider three radically different parameterizations: (a) a baseline model that we calibrate to match the interwar period; (b) a case that holds the aggregate capital stock fixed; and (c) a model without intermediate inputs.

The first panel of Table 4 presents the results with parameters set as in Table 3 . As is evident, the tariff war causes all macroeconomic aggregates except tariff revenue to decline. When tariffs rise from 10 percent to 30 percent, the largest decline occurs in exports at 9.7 percent, followed by investment at 3.1 percent, output at 2.1 percent, consumption at 1.8 percent, and effort at 1.5 percent. Tariff revenue rises by 171 percent. The export multiplier for the baseline case is 3.1.

To put these results in perspective, suppose we had ignored our tariff measures and increased tariff levels in the model until we produced the 50 percent real decline observed in U.S. exports from 1929 to 1933. Our model would be capable of explaining one-third of the real decline in output over this period! However, tariff increases required to generate such a large drop in world trade are implausible given our empirical estimates of international tariff levels, even allowing for a generous view of their inherent downward bias. Applying this empirical discipline, the model predicts export declines of between 10 and 20 percent in the baseline version (see Table 4). These export declines translate into output declines of between 2 and 5 percent, which amount to between 7 and 16 percent of the decline in output observed in the United States from 1929 to 1933.

The substantive declines in output that our model predicts can be traced to the interaction of capital accumulation and production distortions introduced by tariffs on intermediate goods. The second panel of Table 4 holds capital fixed, as is assumed in many of the early CGE exercises. We see that while the impact of the tariff war has a similar impact on exports, the export multiplier is only 1.3 , so the aggregative effects are modest. Output falls by 0.8 percent, about two-thirds less than in the baseline case.

Similar results obtain when capital is allowed to vary but intermediate inputs are dropped from the model. While the export multiplier is again about 1.3 in this case, exports decline by more, so the output effects are somewhat 
Table 4. Steady-state results with symmetric retaliation: The role of capital, materials, and tariff measurement

\begin{tabular}{|c|c|c|c|}
\hline & Steady-state level & Case I & Case II \\
\hline \multicolumn{4}{|c|}{ Panel A: Baseline parameterization } \\
\hline Output & 100 & -2.1 & -4.9 \\
\hline Consumption & 80 & -1.8 & -4.3 \\
\hline Investment & 20 & -3.1 & -7.2 \\
\hline Effort & 0.27 & -1.5 & -3.4 \\
\hline Exports & 7 & -9.7 & -20.3 \\
\hline Export multiplier & - & 3.1 & 3.4 \\
\hline Tariff revenue & 0.7 & +171 & +377 \\
\hline \multicolumn{4}{|c|}{ Panel B: Fixed world capital } \\
\hline Output & 100 & -0.8 & 1.9 \\
\hline Consumption & 80 & -1.0 & -2.4 \\
\hline Investment & 20 & 0.0 & 0.0 \\
\hline Effort & 0.27 & -1.0 & -2.3 \\
\hline Exports & 7 & -8.5 & -17.9 \\
\hline Export multiplier & - & 1.3 & 1.5 \\
\hline Tariff revenue & 1.2 & +174 & +391 \\
\hline \multicolumn{4}{|c|}{ Panel C: No materials } \\
\hline Output & 100 & -1.4 & -2.8 \\
\hline Consumption & 80 & -1.4 & -2.9 \\
\hline Investment & 20 & -1.3 & -2.6 \\
\hline Effort & 0.27 & -1.3 & -2.6 \\
\hline Exports & 7 & -15.4 & -31.2 \\
\hline Export multiplier & - & 1.3 & 1.3 \\
\hline Tariff revenue & 0.7 & +151 & +303 \\
\hline
\end{tabular}

Note: Baseline refers to the parameterization described in Table 3, except that for $\theta=0$, the consumption share parameters $\left(b_{i}\right)$ are altered to keep the export/GNP ratio approximately at 0.07 . The values are $b_{1}=$ $0.82, b_{2}=b_{3}=0.09$. Steady-state levels are normalized such that output equals 100 . Case I has tariffs rising from $10 \%$ to $30 \%$ both at home and abroad, and Case II has tariffs rising from $10 \%$ to $60 \%$ both at home and abroad. Results are identical across countries due to the symmetry of the model and the assumption of symmetric retaliation.

larger here compared to the fixed capital case. However, output still falls by only 1.4 percent, one-third less than in the baseline.

The impact of tariffs on effort is determined by three factors. First, the tariff distortion lowers the value marginal product of labor in precisely the same way that it has lowered the value marginal product of capital. Second, a lower steady-state capital stock lowers the marginal product of labor. Both of these effects operate to reduce the equilibrium wages and the level of effort. 
Third, individuals have suffered a negative wealth effect associated with the increase in global tariff levels, which increases the equilibrium amount of effort. The substitution effect of a lower wage dominates the wealth effect in our model, so effort falls.

We can use similar reasoning to explain the consequence of holding capital fixed. With capital held fixed, the tariff on materials no longer results in a lower steady-state capital stock. The wage is reduced by the higher price of materials as before, but this is not reinforced by a decline in capital. Consequently, effort declines by only 1.0 percent when capital is held fixed, compared to 1.5 percent when capital is allowed to vary. The output effects are dramatically reduced when capital is held fixed, first, by eliminating the direct effect of a lower steady-state capital stock and, second, by mitigating the reduction of the decline in effort. As we see in Table 4, the result is to reduce the export multiplier from 3.1 to 1.3 .

The consequences of ignoring tariffs on intermediate inputs is easy to understand given the interpretation of this tariff as a distortion to the value marginal product of each factor of production. Our previous discussion indicated that this will reduce the aggregate effect of tariffs. Another interesting feature of the last panel of Table 4 is that the effects of a consumption tariff are basically uniform across output, consumption, investment, and effort. Absent the production distortion, there is little to change real wages in equilibrium. At a constant wage-rental ratio, capital and labor must fall by the same proportion, and this carries over directly to output. Thus, tariffs on intermediate inputs not only increase the magnitude of changes in aggregate variables like output, but also call forth very different quantitative responses from the components of national income.

Before concluding the steady-state results and moving on to time series simulations, we investigate the sensitivity of the baseline model to alterations in the degree of substitutability between domestic and foreign goods. ${ }^{4}$ Table 5 reports the results of these experiments. The first column repeats the steady state of the world economy and the baseline results, from Table 4, for comparison purposes. Columns 2 and 3 examine the sensitivity of the results to substitutability across consumption goods for the range of empirical estimates documented by Whalley (1985). Except for exports, the quantitative effects are larger the lower the elasticity of substitution in consumption, but for a wide range of elasticities, the predicted impacts on output, investment, consumption, and employment are basically identical.

The results for the material inputs are only slightly more sensitive to the elasticity of substitution parameter with the volume of trade now declining by 25.6 in the case of higher elasticity of substitution, and by only 16 percent in the case of lower substitution. As one would expect, the less substitutable 
Table 5. Steady-state results with symmetric retaliation: Sensitivity analysis

\begin{tabular}{|c|c|c|c|c|c|}
\hline \multirow[b]{3}{*}{ Aggregate } & \multirow{3}{*}{$\begin{array}{c}\text { Baseline } \\
(1,0.625)\end{array}$} & \multicolumn{4}{|c|}{ Elasticity of substitution in: } \\
\hline & & \multicolumn{2}{|c|}{$\begin{array}{l}\text { Consumption } \\
1 /(1+\gamma)\end{array}$} & \multicolumn{2}{|c|}{$\begin{array}{c}\text { Materials } \\
1 /(1+\sigma)\end{array}$} \\
\hline & & 0.5 & 1.5 & 0.4 & 0.9 \\
\hline & (1) & (2) & (3) & (4) & (5) \\
\hline Output & -4.9 & -4.9 & -4.8 & -5.1 & -4.7 \\
\hline Consumption & -4.3 & -4.3 & -4.2 & -4.4 & -4.2 \\
\hline Investment & -7.2 & -7.3 & -7.2 & -7.6 & -6.9 \\
\hline Effort & -3.4 & -3.5 & -3.2 & -3.7 & -3.1 \\
\hline Exports & -20.3 & -18.9 & -21.5 & -16.0 & -25.6 \\
\hline Export multipliers & 3.4 & 3.7 & 3.2 & 4.5 & 2.6 \\
\hline Tariff revenue & 377 & 385 & 370 & 402 & 345 \\
\hline
\end{tabular}

Note: Baseline refers to the parameterization described in Table 3. The weighting parameters in the aggregator functions for consumption and materials are altered across cases to keep the share of exports approximately equal across cases.

the domestic and foreign materials, the greater the impact of a tariff on the supply side. We see this in the larger declines in investment, effort, and output in column 4 relative to column 5 . Again, however, the quantitative impact of the tariff increase on these variables is broadly similar across a wide range of parameter values.

The general lesson here is that the key elements of the model that generate significant macroeconomic effects of tariffs are the presence of material inputs and endogenous capital accumulation. The results are insensitive to the choice of parameters once these features of the model are present. While the tariff war results in a collapse of world trade independently of whether trade and tariffs involve final goods or intermediate imports, the macroeconomic repercussions stem from the interaction of distorted material prices and the dynamic propagation of these effects through capital accumulation and labor supply decisions.

\section{Implications for Business Cycles}

The fact that tariffs varied in a cyclical fashion is readily apparent in Figure 1, which plots three tariff indexes annually from 1920 to 1940 in percentage deviations from their sample means. The figure presents two estimates of the aggregate tariff level for the United States and one for its major trading partners. The first of the U.S. estimates takes tariff revenue and divides by total imports, while the second takes tariff revenue and divides by dutiable 
imports. In our model we treat all imports as dutiable so that if we utilize the index that incorporates only dutiable imports, we are applying the tariff rate to a greater volume of imports than were actually subject to tariffs. Using the index computed from total imports, we are applying a downward-biased tariff to all imports. In the case of the European countries, we only have tariff indexes computed as tariff revenue divided by total imports.

The source of the cyclicality is largely due to the use of specific duties during this period of history. Specific duties are tariff levies assessed in nominal currency per physical unit imported. This fact, combined with considerable nominal price variation and few (though sometimes dramatic) legislative adjustments, imparts a strong negative correlation between the ad valorem equivalent tariff rates and the price level. In fact, Crucini (1994) finds that most of the interwar variation in U.S. tariff levels originated from this source.

We see in Figure 1 that the U.S. index using only dutiable imports is much more variable than the index constructed using total U.S. imports. Note that in addition to the notorious increases of the early 1930s, there was a comparable increase in tariff rates in 1920-21. Just as the tariff increases in the early 1930s were a mix of legislative changes (Hawley-Smoot) and price deflation, the increases in the early 1920s reflected both legislated increases (the Emergency Tariff Act and the Fordney-McCumber Tariff Act) and the effect of postwar price deflation.

Viewing the U.S. tariff indexes along with their foreign counterparts paints a classic picture of the global escalation of tariff levels during the interwar

Figure 1. Ad valorem equivalent tariff levels expressed as percentage deviations from their sample averages

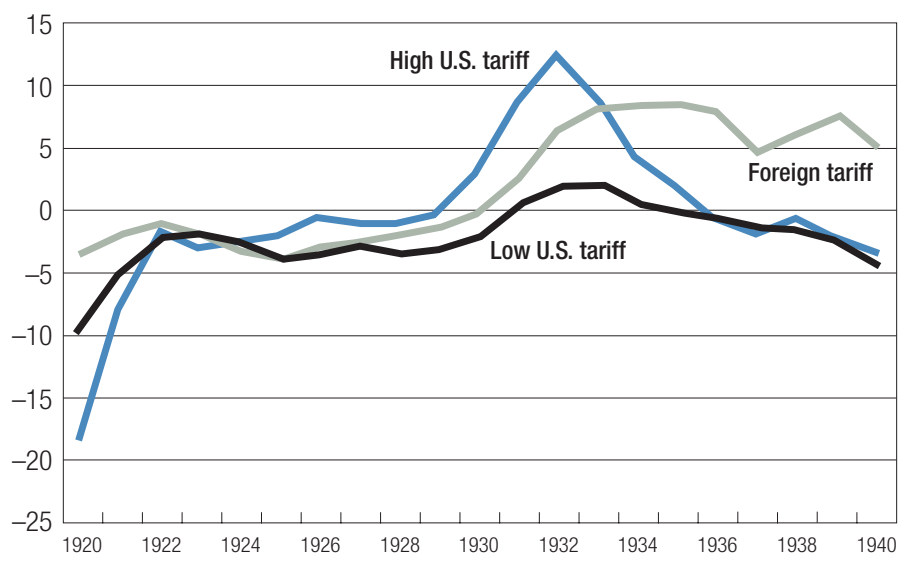


period. The figure also shows that foreign tariff levels did not rise abruptly following the passage of the Hawley-Smoot Tariff Act in 1930, but increased gradually throughout much of the period.

Our earlier paper conducted a simulation exercise in which the tariff sequences were fed into the dynamic equilibrium model to produce simulated paths of U.S. and foreign aggregates. The exact index used influenced the quantitative results, but the qualitative picture was close to one involving a symmetric tariff war, with tariffs escalating in tandem over time. Because there is a tendency for tariff levels estimated using tariff revenue data to systematically understate actual legislated tariff levels, and to ensure that we convey the gist of our results, we focus on a case in which the U.S. and foreign tariff levels both follow the path of the U.S. tariff rate computed as the ratio of customs duties to dutiable imports (the blue line in Figure 1).

Figure 2 presents the paths of output, consumption, and effort from 1928 to 1940 . We see that the model predicts about a 2 percent drop in output and effort relative to the steady state between 1928 and the trough in 1932. Moreover, output does not recover to its steady-state level until 1937, so that output is below the steady state for seven years. We know of no other quantitative exercise that produces such a large and sustained decline in U.S. output as a result of commercial policy. Of course, in the context of the Great Depression, the quantitative decline is small and its duration too short. We turn to these issues in the next section, which examines the cyclical impact of tariffs in the context of efficiency effects and labor market distortions.

Figure 2. Simulation of a symmetric tariff war

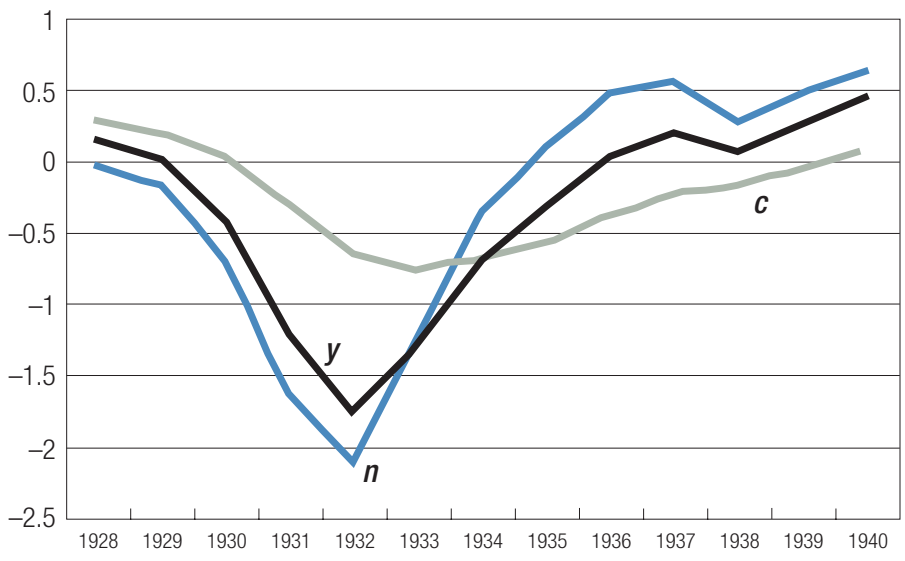




\section{The Prototype Economy}

Here we undertake to show how our model, notwithstanding its complexity - two countries, three types of output in each country, three consumption goods, material inputs - can be represented by a "prototype economy" of the sort that Chari, Kehoe, and McGrattan (2002) use for business cycle accounting. For illustrative purposes, and to reduce somewhat the complexity of the calculations, we will focus on the symmetric case in which both countries impose the same tariffs at the same time. In this case the prototype is a one-sector closed economy neoclassical growth model with two relatively straightforward distortions represented by linear taxes.

In the prototype model, a representative consumer solves

$$
\max E_{t-1}\left\{\sum_{s=t}^{\infty} \beta^{s-t}\left[\log \left(C_{s}\right)+v\left(1-N_{s}\right)\right]\right.
$$

subject to a budget constraint

$$
C_{t}+K_{t+1} \leq K_{t}(1-\delta)+w_{t} N_{t}\left(1-\tau_{N t}\right)+r_{t} K_{t}\left(1-\tau_{K t}\right)+T_{t} .
$$

The representative firm chooses $K_{t+1}$ and $N_{t}$ to maximize

$$
\sum_{s=t}^{\infty} Z_{t s}\left[A_{s} F\left(K_{s}, N_{s}\right)-w_{s} N_{s}-r_{s} K_{s}\right]
$$

where $Z_{t s}=\Pi_{j=t+1}^{s}\left(1+r_{j}\right)^{-1}(s \geq t+1), Z_{t t}=1$. The corresponding economywide resource constraints are

$$
\begin{aligned}
& A_{t} F\left(K_{t}, N_{t}\right)-C_{t}-\Delta K_{t+1}-\delta K_{t} \geq 0 \\
& \tau_{K t} K_{t}+\tau_{N t} N_{t}=T_{t}
\end{aligned}
$$

We will show how the macroeconomic effects of the changes in tariff levels during the Great Depression may be represented as a combination of an efficiency effect (decreasing $A$ ) and a wage tax (increasing $\tau_{N}$ ).

\section{Productivity Disturbances and Efficiency Wedges}

Consider the analogous problem solved by a representative firm in one of our production sectors, but with intermediate inputs into production and no productivity variation. Keep in mind that we assume that $\theta_{i}=\theta$ and $\alpha_{i}=\alpha$ and that factor inputs are freely mobile across sectors within countries, so it must be the case that the capital-labor ratios are identical across sectors. The 
implication is that the prices of sectoral goods move in lockstep, though they may change relative to $p_{m t}$ (which is the price of materials produced via the Armington aggregator). That being the case, we may drop the $i$ subscript and normalize nominal wages by the common final goods price:

$$
\sum_{s=t}^{\infty} Z_{t s}\left[F\left(K_{s}, N_{s}, M_{s}\right)-w_{s} N_{s}-r_{s} K_{s}-p_{m s} M_{s}\right]
$$

where $Z_{t s}$ is the discount factor from $t$ to $s$ as defined following equation (15).

There are two differences between this problem and the previous onesector planner's problem: the output concept in this maximization problem is gross output, and there are three inputs into production, the new one being materials. This is where the Leontief (1941) assumption for materials is convenient, as may be seen by imposing $M_{s}=\theta Y_{s}$ at the outset:

$$
\sum_{s=t}^{\infty} Z_{t s}\left[\left(1-\theta p_{m s}\right) F\left(K_{s}, N_{s}\right)-w_{s} N_{s}-r_{s} K_{s}\right]
$$

From the point of view of the decision problem of an atomistic firm, $p_{m t}$ is exogenous and shifts the labor and investment demand schedules of the firm in exactly the same way as a total factor productivity change would in the basic neoclassical model.

To see this more clearly, consider the first-order conditions for labor $N_{t}$ and capital $K_{t}$ in our trade model:

$$
\begin{aligned}
& \left(1-\theta p_{m t}\right) D_{2} F\left(K_{t}, N_{t}\right)=w_{t} \\
& \left(1-\theta p_{m t}\right) D_{1} F\left(K_{t}, N_{t}\right)=r_{t}
\end{aligned}
$$

and the analogous conditions for the prototype economy:

$$
\begin{aligned}
& A_{t} D_{2} F\left(K_{t}, N_{t}\right)=w_{t} \\
& A_{t} D_{1} F\left(K_{t}, N_{t}\right)=r_{t} .
\end{aligned}
$$

Thus, the efficiency wedge implied by the trade model is the level of productivity (common to all sectors) that would give rise to the same input choices by the firm, namely,

$$
A_{t}=\left(1-\theta p_{m t}\right)
$$


where it is understood that $p_{m t}$ is the price of materials relative to the price of final goods.

Suppose that we were modeling the United States as a small open economy. In that environment, we would take the foreign price of materials as given (as we did in the firm-level problem) and the domestic price would be $p_{m t}=\left(1+\tau_{t}\right) p_{m}^{*}$, where $\tau_{t}$ is the ad valorem equivalent tariffs on imports of foreign materials and $p_{m}^{*}$ is the foreign ("world") price of materials, which we normalize to unity in the steady state. The magnitude of the change in the efficiency wedge in the prototype model that would produce the same marginal effects on the productivity of capital and labor (holding fixed the world price of materials) as the tariff changes would be

$$
\begin{aligned}
& A_{t}=\left(1-\theta\left(1+\tau_{t}\right)\right) \\
& \hat{A}_{t} \equiv-\varphi \hat{\Omega}_{t} \\
& \varphi \equiv \frac{\theta(1+\tau)}{(1-\theta(1+\tau))}
\end{aligned}
$$

where $\Omega_{t} \equiv 1+\tau_{t}$. For an initial tariff level of zero, $\varphi$ is the ratio of materials cost to value added, which equals 0.25 in our baseline calibration. Combined with an initial tariff level of 10 percent gives us $\varphi=0.282$. Thus, an increase in tariffs from 10 percent to 60 percent (the trough-to-peak movement in the U.S. tariffs as measured by customs duties relative to dutiable imports) would be equivalent to a productivity drop of 12.8 percent, which would translate into an 18.7 percent drop in output (in the calibrated prototype model) if the tariff increase was viewed as permanent. Unfortunately, this estimate is problematic because it ignores foreign tariff retaliation and the fact that the countries imposing the tariffs are large enough to affect world prices.

In our general equilibrium model, the prices of domestic and foreign materials are endogenous, which complicates the intuition somewhat and alters the quantitative implications. The wedge in our general equilibrium model is

$$
A_{t}=1-\theta \frac{\left(1+\tau_{4 t}\right)}{D_{2} G\left(m_{h h t}, m_{f h t}\right)}
$$

where the materials price is substituted out using the first-order condition for the choice of imported materials used by the home country (i.e., $\left.p_{m t} D_{2} G\left(m_{h h t}, m_{f h t}\right)=\left(1+\tau_{t}\right) p_{4 t}^{*}\right)$ and we have incorporated the fact that 
within-country final goods prices are equal in our model (both in the steady state and over time). The only difference between this wedge and that in the small open economy is the appearance of $D_{2} G\left(m_{h h t}, m_{f h t}\right)$ in the denominator, which is the marginal product of foreign materials in the provision of the domestic aggregate material input.

Two factors work to mitigate the impact of tariffs on aggregate economic activity relative to the small open economy benchmark. First, there is a termsof-trade effect such that when the home country raises its tariffs, it tends to reduce the world relative price of materials. Thus, the new equilibrium relative price of materials rises by less than the increase in the tariff. In a symmetric tariff war, however, this effect is inoperative. The second factor absent in the partial equilibrium model is the presence of domestic producers of material inputs. The quantitative response of domestic producers will depend to a significant extent on the elasticity of substitution between domestic and foreign materials. The implication, though, is that an expansion of domestic materials production mitigates the materials price increase and reduces the aggregative impact of the tariff war. This effect is operative even in a symmetric tariff war, since both countries have domestic materials producing sectors. As it turns out, the peak-to-trough movement in the efficiency wedge is just over 1 percent once these general equilibrium effects are taken into account - approximately one-tenth of what the partial equilibrium analysis suggested.

\section{Labor Wedge}

Next consider the impact of $\tau_{3}$ on domestic consumption decisions. There are two dimensions on which to consider this impact: static and intertemporal. The static impact of $\tau_{3}$ is reflected by the marginal rate of substitution between goods 1 and 3:

$$
\frac{b_{3}}{b_{1}}\left(\frac{C_{3 t}}{C_{1 t}}\right)^{-(1+\gamma)}=\frac{p_{3 t}^{*}\left(1+\tau_{3 t}\right)}{p_{1 t}}
$$

Substituting this and first-order conditions involving $C_{1}$ and $C_{2}$ into the definition of $C, C \equiv\left[b_{1} C_{1}^{-\gamma}+b_{2} C_{2}^{-\gamma}+b_{3} C_{3}^{-\gamma}\right]^{-(1 / \gamma)}$, and one can show that

$$
C_{t} \equiv\left[b_{1}^{\frac{1}{1+\gamma}} p_{1 t}^{\frac{\gamma}{1+\gamma}}+b_{2}^{\frac{1}{1+\gamma}} p_{2 t}^{\frac{\gamma}{1+\gamma}}+b_{3}^{\frac{1}{1+\gamma}}\left[p_{3 t}^{*}\left(1+\tau_{3 t}\right)\right]^{\frac{\gamma}{1+\gamma}}\right]^{-\frac{1+\gamma}{\gamma}}
$$

The first-order condition for $C_{t}$ and $N_{t}$ in the prototype economy is 
(30) $\frac{1 / C_{t}}{v^{\prime}\left(1-N_{t}\right)}=\frac{1}{w_{t}\left(1-\tau_{N_{t}}\right)}$.

This suggests that we could set

(31) $1-\tau_{N_{t}}=\left[\frac{b_{1}^{\frac{1}{1+\gamma}} p_{1 t}^{\frac{\gamma}{1+\gamma}}+b_{2}^{\frac{1}{1+\gamma}} p_{2 t}^{\frac{\gamma}{1+\gamma}}+b_{3}^{\frac{1}{1+\gamma}}\left[p_{3 t}^{*}\left(1+\tau_{3 t}\right)\right]^{\frac{\gamma}{1+\gamma}}}{b_{1}^{\frac{1}{1+\gamma}} p_{1 t}^{\frac{\gamma}{1+\gamma}}+b_{2}^{\frac{1}{1+\gamma}} p_{2 t}^{\frac{\gamma}{1+\gamma}}+b_{3}^{\frac{1}{1+\gamma}}\left[p_{3 t}^{*}\right]^{\frac{\gamma}{1+\gamma}}}\right]^{-\frac{1+\gamma}{\gamma}}$,

which of course equals 1 if $\tau_{3 t}=0$, and is decreasing in $\tau_{3 t}$ for $\gamma>-1$. This reflects the fact that the tariff in effect reduces real wages by making the preferred consumption bundle more expensive.

\section{Comparing the Tariff and Historical Wedges}

We next compute the implied wedges, given our baseline parameterization, for the symmetric case, based on the high tariff series shown earlier in Figure 1. While these are not strictly comparable to the historical experience (because we have not incorporated in the prototype model the asymmetric behavior of foreign tariffs), they nonetheless provide a close approximation of the tariffs' impact. This may be verified by comparing the simulations reported

Figure 3. U.S. GDP and the labor and efficiency wedges implied by the trade model viewed through the lens of the prototype aggregate neoclassical model. All series are normalized to 100 in 1929.

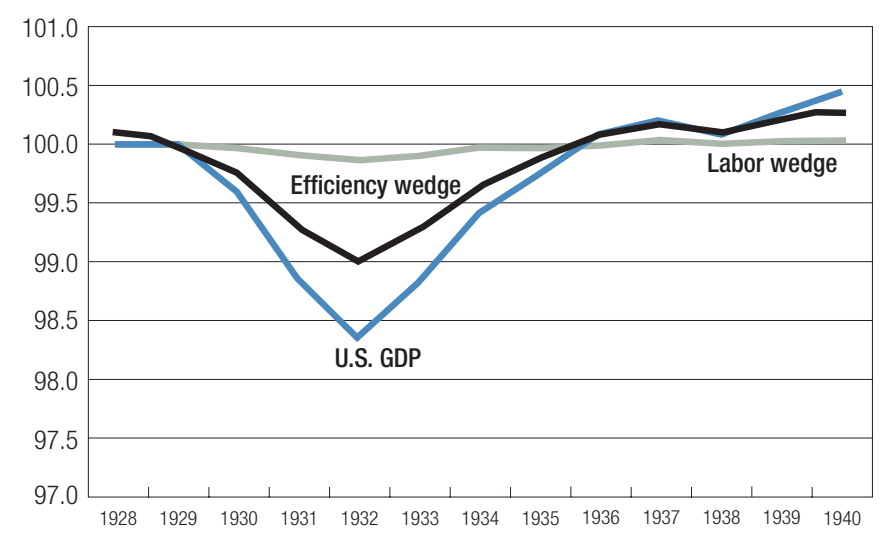


here with the asymmetric tariff simulations in our earlier paper.

We see in Figure 3 that what is needed in the prototype model to match the path of output predicted by the tariff-driven trade model is mostly an efficiency wedge. In comparison to the wedges measured by Chari, Kehoe, and McGrattan (2002) in Figure 4, the efficiency wedge correlates very strongly with the model simulation during the entire sample period. The small labor wedge produced by the consumption tariff in our model declines at the same time as the empirical labor wedge from 1929 to 1993, but we predict a rising labor wedge (declining distortion) as the tariff levels fall from 1933 onward. Both empirical wedges are at least an order of magnitude larger than those produced by our simulation, which simply reflects the fact that our model can only account for, at most, 10 percent of the swing in output during the Great Depression.

Care should be taken in interpreting the estimated labor and efficiency wedges coming from the trade model and those estimated by Chari, Kehoe, and McGrattan. Although tariffs in our model produce distortions resulting in lower real output, they do not directly imply either reductions in total factor productivity (TFP) or failures of the first-order condition linking the marginal rate of substitution of consumption and leisure to the marginal product of labor to hold. The fact that researchers find such "wedges" using the measures and aggregation methods of the basic neoclassical model raises some interesting questions in the context of quantitative business cycle analysis. Specifically, under what circumstances could the tariff-induced distortions as described by our model lead to empirical efficiency or labor wedges? For

Figure 4. U.S. GDP and the labor and efficiency wedges estimated by Chari, Kehoe and McGrattan (2002). All series are normalized to 100 in 1929.

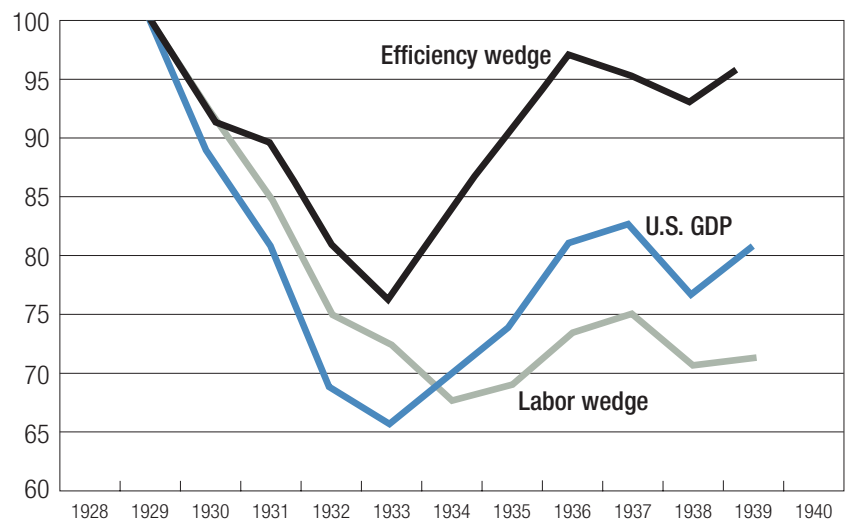


example, a model in which changes in labor inputs are correlated with reductions in (unobservable) work effort (i.e., labor hoarding) could have such an impact. A second question concerns the Chari, Kehoe, and McGrattan business cycle accounting framework. If the distortions induced by our tariffs do not yield observable wedges in their methodology, then where do they show up? It would seem that the Chari, Kehoe, and McGrattan framework is not well suited to account for these distortions.

\section{Conclusions}

In this paper we have revisited the issues addressed in Crucini and Kahn (1996) in light of recent research on the Great Depression. In that paper we had argued that particular features of the Hawley-Smoot tariffs could have provided them with a stronger impact than conventional wisdom had held, and we described the magnitudes in a calibrated general equilibrium model. We suggested that while the tariffs could directly account for only a small part of the Great Depression, they nonetheless had a significant, recession-sized impact - "small" only in the context of the Great Depression.

Here we have reformulated our arguments in the context of the business cycle accounting framework of Chari, Kehoe, and McGrattan (2002). We have shown that tariff increases in our model surface mostly as variation in aggregate efficiency with a small role for the labor wedge. Although the implied efficiency wedges from tariffs do not translate into measured TFP declines, their correlation with the Chari, Kehoe, and McGrattan efficiency wedges during the Great Depression suggests the possibility of a connection, either through measurement issues or through some propagation mechanism. In any case, the methodology allowed us to discuss the quantitative impact and aggregate channels by which tariffs affect macroeconomic aggregates in a manner that may be easily understood by economists familiar with the inner workings of the one-sector stochastic growth model.

We regard our findings as only the beginning of an effort to understand the role of tariffs in the Depression. In a sense we have argued that the shocks were larger than might have been previously thought, but with conventional propagation the contribution was modest relative to the scale of the Depression. If wages are sticky above market-clearing levels, then a decline in aggregate efficiency (from whatever source) should result in a larger quantitative impact than under flexible prices. In fact, in their paper in this volume, Perri and Quadrini use wage rigidities to amplify the impact of tariffs in their study of the Great Depression in Italy. Moreover, for any event of such magnitude, it is likely that there were many contributing factors. Any effort to account for the Depression will likely have to look for both large shocks and nonstandard propagation mechanisms before a sufficient understanding is reached. 


\section{Data Appendix}

The macroeconomic aggregates - output, prices, investment, merchandise exports, merchandise imports, and consumption for Canada, Italy, the United Kingdom, and the United States - were generously provided by David Backus. They are described in detail in Backus and Kehoe (1992).

The trade data reported in Table 1 are taken from the League of Nations. II. Economic and Financial, 1931, columns 1-2 Table X, columns 3-9 Table XI, except Canada. Canadian data in columns 1 and 2 are from the Canada Yearbook External Trade Table XI (fully manufactured and aggregate of raw materials and partly manufactured).

The tariff indexes for Germany, Italy, Sweden, and the United Kingdom were computed as the ratio of customs revenue to total imports and are from European Historical Statistics 1750-1970.

The tariff indexes for Canada are from Canada Year Book, selected years.

The tariff indexes for the United States and imports by country of origin are from The Statistical History of the United States, from Colonial Times to the Present.

The trade-weighted tariff levels (in Table 2) use the shares of U.S. imports from each country in 1929 normalized to total 100 . The countries included in the calculation were Canada, France, Germany, Italy, and the United Kingdom. U.S. export shares are used because we are assuming that the world consists of the United States and these countries, and we are ignoring imports of these countries from countries other than the United States. Thus, we are also assuming that tariffs were imposed on imports independent of the country of origin. To the extent that countries were retaliating directly against the United States, we are understating the magnitude of the tariff increases.

For the business cycle simulations, the tariff levels are transformed to log deviations from their sample means to correspond to the units of the linearized model, which measures aggregate variables in log deviations from their steady-state growth path. The U.S. tariff and rest-of-the-world tariff levels correspond to the U.S. index using dutiable imports.

\section{Notes}

We are grateful to Rick Bond, Timothy Kehoe, Andrea Maneschi, and Ananth Ramanarayanan for helpful comments. The views expressed herein are those of the authors and not necessarily those of the Federal Reserve Bank of New York or the Federal Reserve System. Portions of this paper were reprinted from "Tariffs and Aggregate Economic Activity: Lessons from the Great Depression,” Journal of Monetary Economics 38, no. 3 (1996): 427-67.

1. Jones (1934) discusses the question of retaliation in detail.

2. The details of the political economy of the Canadian tariff increases have recently been studied by McDonald, O'Brien, and Callahan (1997). 
3. Note that this is approximately the same as the fraction of U.S. imports categorized as nonmanufactured in Table 1, which is not nearly as precise a disaggregation of commodities as in Leontief 's input-output analysis.

4. In these experiments we are careful to alter the share parameters for domestic and foreign goods as we vary the elasticity of substitution. To see why this is necessary, consider the condition for the choice of domestic versus foreign materials: $m_{h h} / m_{f h}=[(\psi /(1-\psi))(1+\tau)]^{1 /(1+\sigma)}$. From this equation we see that reducing the elasticity of substitution has the effect of reducing the use of domestic materials relative to foreign materials for given values of $\psi$ and $\tau$. Since the left side of this expression is pinned down by a steady-state ratio (the ratio of domestic materials to imported materials used in production of intermediate products), we hold it fixed as we alter the elasticity of substitution, $\sigma$, by adjusting the parameter $\psi$.

\section{References}

Armington, Paul S. 1969. A theory of demand for products distinguished by the place of production. International Monetary Fund Staff Papers 16 (March): 159-78.

Backus, David K., and Patrick J. Kehoe. 1992. International evidence on the historical properties of business cycles. American Economic Review 82 (September): 864-88.

Chari, V. V.; Patrick J. Kehoe; and Ellen R. McGrattan. 2002. Business cycle accounting. Working Paper 625. Federal Reserve Bank of Minneapolis.

Crucini, Mario J. 1994. Sources of variation in real tariff rates: The United States, 1900 to 1940. American Economic Review 84 (June): 732-43.

Crucini, Mario J., and James Kahn. 1996. Tariffs and aggregate economic activity: Lessons from the Great Depression. Journal of Monetary Economics 38 (December): 427-67.

Eichengreen, Barry. 1989. The political economy of the Smoot-Hawley Tariff. Research in Economic History 12: 1-43.

Galí, Jordi; Mark Gertler; and David López-Salido. 2001. Markups, gaps, and the welfare costs of fluctuations. Manuscript.

Hall, Robert E. 1997. Macroeconomic fluctuations and the allocation of time. Journal of Labor Economics 15 (January): 223-50.

Irwin, Douglas A., and Randall S. Kroszner. 1996. Log-rolling and economic interests in the passage of the Smoot-Hawley Tariff. Carnegie-Rochester Series on Public Policy 45 (December): 173-200.

Jones, Joseph M. 1934. Tariff retaliation: Repercussions of the Hawley-Smoot bill. Ph.D. dissertation. University of Pennsylvania.

Leontief, Wassily. 1941. The structure of the American economy, 1919-1939: An empirical application of equilibrium analysis. Cambridge, MA: Harvard University Press.

McDonald, Judith A.; Anthony P. O'Brien; and Colleen M. Callahan. 1997. Trade wars: Canada's reaction to the Smoot-Hawley Tariff. Journal of Economic History 57 (December): 802-26. 
Tariffs and the Great Depression

Crucini, Kahn

Mulligan, Casey B. 2002a. A dual method of empirically evaluating dynamic competitive equilibrium models with market distortions, applied to the Great Depression and World War II. Working Paper 8775. National Bureau of Economic Research.

2002b. A century of labor-leisure distortions. Working Paper 8774. National Bureau of Economic Research.

Rogerson, Richard. 1988. Indivisible labor, lotteries, and equilibrium. Journal of Monetary Economics 21 (January): 3-16.

Taussig, Frank W. 1931. The tariff history of the United States, 8th ed. New York: Putnam \& Sons.

Whalley, John. 1985. Trade liberalization among major world trading areas. Cambridge, MA: MIT Press. 
